\title{
A TWELFTH LINKAGE GROUP OF THE HOUSE MOUSE
}

\author{
R. A. FISHER and G. D. SNELL \\ Department of Genetics, University of Cambridge, England, and Roscoe B. Jackson \\ Memorial Laboratory, Bar Harbor, Maine, U.S.A.
}

Received I 7.i.48

IN I94I a new gene mutation was introduced under the name of " jerker," $j e$, in a note by Grüneberg, Burnett and Snell. The mutant was recessive and a close mimic of the longest-known mutant of the kind, "waltzer," $v$. It was tested for linkage much more thoroughly than is usually possible with a new factor. The note gives prima facie evidence for inheritance independent of the following factors, to which where possible the number of the chromosome has been added :

\section{Factor}

Agouti (V) .

Brown (VIII)

Albino (I)

Caracul (VI)

Dilution (II)

Rex (VII) .

\author{
Dominant and recessive pied (III) \\ Brachyury (IX) \\ Flexed \\ Leaden \\ Waltzer $(\mathrm{X})$ \\ Wavy-one (XI)
}

In spite of these thorough tests, no linkage was found, a fact which is not surprising when we consider that the total length of chromosome excluded was perhaps only about a quarter of the entire range of sites possible.

The factor Dunn's ruby was reported by Dunn in 1945 from stock obtained from Dr C. H. Danforth. Dunn showed that this factor, while phenotypically equivalent to the ruby reported previously by So and Imai $\left(p^{*}\right)$, was not an allelomorph of pink-eye $(p)$, or of pallid $(p a)$, or of albinism $(c)$. It was apparently inherited independently of $p$, and therefore not in the first chromosome.

In January 1947 two intercross matings were made between double heterozygotes for jerker and Dunn's ruby, with a view to introducing these two factors into Line number 3 of the lines set up at the Genetical Department at Cambridge. One of these matings, though not the other, threw an apparent excess of double recessives, and attracted attention to the possibility that these two factors, neither of which had previously been assigned to any linkage group, were mutually linked, and therefore constituted the foundation of a new group. To this group, and to the chromosome which is its physical basis, the Roman numeral XII has been assigned, on the assumption that XI will be used for white and wavy-one. It is of course probable 
that the numbering of chromosomes in this way may later require revision, owing to the discovery that groups previously regarded as independent are in reality loosely linked. The provisional use of such numbers has, however, a certain temporary convenience.

In consequence of this observation a series of backcross matings was built up, in the first place in coupling and later, by reason of the delay required for preparation matings, in repulsion also.

About the end of November, seeing that the evidence accumulated to that date had continued to favour the hypothesis of linkage, though with a somewhat high percentage of recombination, the information was sent to Dr G. D. Snell at Bar Harbor who, without the knowledge of the workers at Cambridge, had also come to suspect the existence of this linkage, and had already obtained data somewhat more favourable to its demonstration.

At this date the evidence of the two bodies of material was summarised as in the table, which has been amended to include some further data accumulated in time for publication.

TABLE

\begin{tabular}{|c|c|c|c|c|c|c|c|c|c|}
\hline & \multirow{2}{*}{++} & \multirow{2}{*}{$j e$} & \multirow{2}{*}{$r u$} & \multirow{2}{*}{ ruje } & \multirow{2}{*}{$T$} & \multicolumn{4}{|c|}{ Scored at } \\
\hline & & & & & & 43 per cent. & 44 per cent. & 45 per cent. & $5^{\circ}$ per cent. \\
\hline $\begin{array}{l}\text { Intercrosses } \\
\text { Coupling Cambridge } \\
\text { Repulsion Bar Harbor } \\
\text { Reparbor }\end{array}$ & $\begin{array}{r}147 \\
4 \\
86\end{array}$ & $\begin{array}{r}53 \\
1 \\
31\end{array}$ & $\begin{array}{r}43 \\
2 \\
35\end{array}$ & $\begin{array}{r}19 \\
1 \\
5\end{array}$ & $\begin{array}{r}262 \\
8 \\
157\end{array}$ & $\begin{array}{r}-25 \cdot 3235 \\
+0.4042 \\
+12.5293\end{array}$ & $\begin{array}{r}-17.6244 \\
+0.6127 \\
+14.7952\end{array}$ & $\begin{array}{r}-12.0789 \\
+0.8161 \\
+17.1186\end{array}$ & $\begin{array}{r}+13.3333 \\
+1.7778 \\
+29.7778\end{array}$ \\
\hline \multirow{4}{*}{ 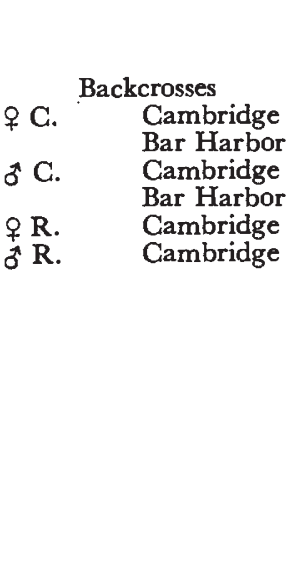 } & \multicolumn{5}{|c|}{ All intercrosses } & $-12 \cdot 3900$ & $-2 \cdot 2165$ & $+5 \cdot 855^{8}$ & $+44 \cdot 8889$ \\
\hline & $\begin{array}{r}51 \\
32 \\
17 \\
20 \\
4 \\
5\end{array}$ & $\begin{array}{r}48 \\
30 \\
12 \\
13 \\
4 \\
5\end{array}$ & $\begin{array}{r}30 \\
31 \\
15 \\
13 \\
6 \\
4\end{array}$ & $\begin{array}{r}44 \\
47 \\
17 \\
14 \\
4 \\
8\end{array}$ & $\begin{array}{r}173 \\
140 \\
61 \\
60 \\
18 \\
22\end{array}$ & $\begin{array}{r}-14 \cdot 7286 \\
-3 \cdot 2640 \\
-3 \cdot 1416 \\
-0.8160 \\
-1 \cdot 0608 \\
-14.4431\end{array}$ & $\begin{array}{r}-7.8298 \\
+2.4350 \\
-0.6493 \\
+1.6234 \\
-0.3247 \\
-13.4741\end{array}$ & $\begin{array}{r}-0 \cdot 6060 \\
+8 \cdot 0808 \\
+1.8182 \\
+4 \cdot 0404 \\
+0 \cdot 4040 \\
-12 \cdot 5253\end{array}$ & $\begin{array}{l}+34 \cdot 0000 \\
+36 \cdot 0000 \\
+14 \cdot 0000 \\
+16 \cdot 0000 \\
+4 \cdot 0000 \\
-8 \cdot 0000\end{array}$ \\
\hline & \multicolumn{4}{|c|}{$\begin{array}{l}\text { All backcrosses } \\
\text { All matings }\end{array}$} & & $\begin{array}{l}-37 \cdot 454 \mathrm{I} \\
-49 \cdot 844^{\mathrm{I}}\end{array}$ & $\begin{array}{l}-18.2195 \\
-20.4360\end{array}$ & $\begin{array}{l}+1.2121 \\
+7.0679\end{array}$ & $\begin{array}{r}+96 \cdot 0000 \\
+140 \cdot 8888\end{array}$ \\
\hline & \multicolumn{6}{|c|}{$\begin{array}{l}\text { Total information : } 2750 \cdot 39 \\
\text { Standard error of score } \\
\text { Significant difference from } 50 \text { per cent. }\end{array}$} & \multicolumn{3}{|c|}{$\begin{array}{l}\text { from Bar Harbor about ro50 } \\
\text { from Cambridge about } 1700 \\
: \cdot \quad \cdot \quad \cdot \chi^{2}=725\end{array}$} \\
\hline
\end{tabular}

It will be seen that nearly all the separate portions here compiled favour linkage, as shown by the positive values at 50 per cent. More data from the repulsion backcrosses are, however, still needed. 


\section{A TWELFTH LINKAGE GROUP OF THE HOUSE MOUSE 273}

Acknowledgement.-The work done at Bar Harbor has been aided by a grant to the Roscoe B. Jackson Memorial Laboratory from the National Cancer Institute.

\section{REFERENCES}

GRÜNEBERG, H., BURNETT, J. B., AND SNELL, G. D. 1941 .

The origin of Jerker, a new gene mutation in the House Mouse, and linkage studies made with it.

Proc. Nat. Acad. Sci. 27, 12, 562-565.

DUNN, L. C. 1945.

A new eye color mutant in the mouse with asymmetrical expression.

Proc. Nat. Acad. Sci. 3I, I I, 343-346.

SNELL, G. D., AND BUNKER, HELEN. 1948.

Linkage of white and waved-I.

Jour. Hered. (in press).

GROBMAN, ARNOLD G., AND CHARLES, DONALD R. 1947.

A new dominant autosomal mutant affecting coat colour in the mouse, Mus. musculus.

Four. Hered. $38,12,3^{81-384}$. 